\title{
THE EFFECT OF USING SENSORY IMAGES AND QUESTIONING STRATEGIES ON THE STUDENTS' ABILITY IN READING COMPREHENSION
}

\author{
Yani Lubis \\ lubis_yani@yahoo.com
}

Lecturer of North Sumatra State Islamic University

\begin{abstract}
Sensory images strategy talks about experience, experience is significant aspect for background knowledge. So, sensory images strategy guides the students to represent of their experience in their memories. The Questioning Strategy is a way of forming questions as you read in order to deepen understanding and enjoyment of the text. The Questions have many deals with clarifying the meaning or a phrase or passage, exploring important themes, considering the author's technique, or learning more about something you find that interesting. The second part of the Questioning Strategy is finding an answer, either on your own or with the help of a teacher or friend. The Aims of Study were to know Students' Understanding to the text when taught with Sensory Images strategy and Students' Understanding to the text when taught with Questioning strategy. To know differences the students' ability in reading comprehension when taught with Sensory Images and Questioning strategies.
\end{abstract}

Key words: Sensory Images Strategy, The Questioning Strategy, and Students' Ability in Reading Comprehension.

\section{INTRODUCTION}

Reading is an interactive process in which reader is actively involved in using available content knowledge and knowledge of the text structure to construct the meaning of the text. ${ }^{1}$ And it is very important for students be an effective means of expanding and improving the students' English as well as enriching their experience and intellectual ability. As a medium of commutation and tool of learning, reading serves an indispensable function in society. But it is not a sample job to do, because reading invalves when we read a subject, perceiving when we want to understand materials and

'Byrd, Particia, (1995), Material Writers' Guide, USA: Heinle \& Heinle Publishers, , p. 81 
reacting when we want to know what our sample wants to do from the reading text.

Reading text is a set of paragraph that consists of one main idea in it. Because every paragraph gives much information to the students and can enrich our knowledge about it.

Does a mere retelling of what one reads, as is done in some tests of reading comprehension, demonstrate adequate comprehension? The notion of grasping suggests that there is an action required of the reader in order to grasp the meaning of the text. Reading comprehension is not a passive activity in which meaning "magically" appears once the reader reads the words in the text. ${ }^{2}$

To search reading can be used many strategies such as: Sensory Images and Question strategies. The teacher has to try to use these strategies in teaching reading and then to comprehend the text or reading text well, answering the questions from it grammatically, and train them to retell the text by using their own words. By using the two strategies (Sensory Images and Questioning Strategies) are hoped the students can tell their experience or retell the text that they had read and they can answer the questions from the text correctly.

Beside that, the English teacher does not use Sensory Images and Question strategies before, so, that need to know if the teacher uses the two strategies can influence the students' ability in reading comprehension or not. And which both strategies is better to teach reading comprehension.

Questioning has been utilized as a critical assessment tool for centuries. It has been thought that there is a relationship between asking good questions and effective teaching. In order to analyze teachers' questioning strategies from various aspects, this study was conducted during the 2014-2015 academic year with 170 primary school teachers working in the schools located in the center of Gaziantep Province in Turkey. Data were collected through a semi-structured questionnaire prepared by the researchers, and were examined via content analysis. Explanatory mixed method design was used to analyze the research problem. The findings of this study revealed that: (1) Teachers asked divergent questions to draw attention and interest (2) Teachers have misunderstanding of divergent and convergent questions (3) Teachers mostly ask questions to entire class than individual (4) Teachers asked most frequently questions aimed at uncovering operational knowledge and least frequently questions whose goal was to uncover metacognitive knowledge (5) Teachers generally used probing questions, prolonged waiting time and did not ask vague questions (6) Teachers did not use questions as a punishment tool. This study revealed that asking good

\footnotetext{
${ }^{2}$ Danny Brassell, Timothy Rasinski, and Foreword by Hallie Yopp (2008), Comprehension That Works; Taking Students Beyond Ordinary Understanding to Deep Comprehension, Shell Education, Huntington Beach., p. 15-16
} 
questions must be considered more important in pre-service education and teachers must be supported with in-service trainings to be more effective in asking questions. ${ }^{3}$

Sensory experiences are a significant aspect of our background knowledge. Sensory imagery is an important part of our schemas. When we think about our sensory experiences, we are creating representations of those experiences in our memories. In fact, our most powerful memories are attached to sensory experiences. A smell or a taste can trigger a long-cherished recollection bread baking in the oven in grandma's kitchen, the damp earth that signals rebirth in nature each spring. The metaphor of the elephant's ears reminds us that we can tap into all of our senses, not just our sense of sight, as we read. When we bring our sensory knowledge to the reading of a text, we are the directors of the movie that plays inside our heads. The movies we create as we read are richer if they include a variety of sensory details. ${ }^{4}$

Based on the above both quotations can understand that the strategies can help the reader to understand the text clearly. Whether the meaning of the text or the main idea of the text. So, if the teacher can apply the strategies, it can be sure that her/his students can understand the text that have read clearly. So, to prove either both strategy can help the students' understanding the reading text or not, the writer feels interest to conduct mini research on the titled "The Effect of Sensory Images and Questioning Teaching Strategies on the Students' Ability in Reading Comprehension".

In teaching English, there are many strategy that can be used. So, the teacher has to master many strategy. In this study, the writer took two strategies namely Sensory Image and Questioning Strategies. The writer took both strategy, cause, he wants to know differentiate of them, which one both of them more effectively strategy in teaching reading comprehension, especially for students' ability to master or to understand of reading text.

The writer explain both strategy before, it is better if he explains about the terms of strategy first. A good teacher should be able to make students feel happy and comfort in learning teaching process. Because of that, the condition of the class and the way of teacher deliver the material influence students ability in achieving material especially in reading comprehension text lesson. So, the teacher has to be wisdom in using teaching strategy. If the teacher is not wisdom in using teaching strategy the students will be bore.

${ }^{3}$ Bülent Dös*, Erdal Bay, Ceyda Aslansoy, Betül Tiryaki, Nurgül Çetin and Cevahir Duman, (2016), Academic Journal, Educational Research and Reviews, An Analysis of Teachers' Questioning Strategies, Gaziantep University, Nizip Faculty of Education, Turkey, p. 2066

${ }^{4}$ Marzano in Judi Moreillon, (2007), Collaborative Strategies for Teaching Reading Comprehension Maximizing Your Impact, American Library Association, Chicago, USA, p. 39 
Teaching strategy is a way of a material presented during the teaching and learning process. Teaching strategy plays a very important role in increasing the quality of education. There are many teaching strategies can be used. The appropriate strategy will result good result

Although one particular strategy may be well-suited for once, it may not work for another. Therefore, teachers need to assess the strengths of their students, and build on their weaknesses. Strategies should be introduced one to two at a time, gradually increasing in number for students that are new to strategy instruction. Teachers teaching the strategies should integrate their strategy instruction into their ongoing teaching.

According to Raphael et. al., there are three principles of teaching instruction. First, it is imperative that teaching instruction is explicit. Second, the strategies must be modeled by skillful students including teachers and peers. Last, the strategies must be scaffolded by teachers until the students are able to use the strategies successfully while independently study. ${ }^{5}$

Efficiency is critical when teaching at-risk students. This can best be achieved by placing student in an instructional group with others that are at their instructional. If possible, at-risk students should receive extra instructional, with the amount of time depending on the grade level and how far the child is below grade level.

Although it is definitely important for teachers to explicitly model the strategies, they need to also correct any confusion that emerges while students try out their newly gained strategies. It is imperative that teachers remind their students about strategy use, if their students neglect to use the strategies on their own, emphasizing that strong readers use strategies. ${ }^{6}$

Both quotation explained that teaching instruction is explicit, strategies must be modeled by skillful students including teachers and peers, strategies must be scaffolded by teachers until the students are able to use the strategies successfully while independently study, and strategy is imperative. It means that strategy must be mastered both teacher and students, so, the strategy can be used correctly and effectively in teaching learning process.

Fred Nickols said Strategy is a term that comes from the Greek strategia, meaning "gen-eralship." In the military, strategy often refers to maneuvering troops into position before the enemy is actually engaged. In this sense, strategy refers to the deployment of troops. Once the enemy has been engaged, attention shifts to tactics.

\footnotetext{
${ }^{5}$ Raphael, Taffy E., (1982). "Question-Answering Strategies for Children." The Reading Teacher 36, November, 1982: p. 186-190

${ }^{6}$ Mary. T, Brownell, (2000), "Dr. Michael Pressley" in Intervention in School and Clinic. Nov. 2000. pages $105-107$
} 
Here, the employment of troops is central. Substitute "resources" for troops and the transfer of the concept to the business world begins to take form. Strategy also refers to the means by which policy is effected, accounting for Karl von Clause-witz's in statement that war is a continuation of political relations via other means. Given the centuries-old military origins of strategy, it seems sensible to begin our examination of strategy with the military view. For that, there is no better source than Hart. ${ }^{7}$

Based on the above definitions, strategy is term that the way how to imitate from military program. But in education, strategy uses as tools to reach the aims of education itself.

From the above conclusion of teaching strategy definitions can be concluded that teaching strategy is the way how to change peoples' (students') behavior by preparing planning and competency to reach the educational aim itself.

Besides that, there are some factors which influence students' learning activity, they are;

a. the leaner must want something

b. the leaner must notice something

c. the learner must do something

d. the learner must get something ${ }^{8}$

Then, Kinsella observed that the whole process teaching and learning a foreign language should be fun. ${ }^{9}$ So, to create that condition teachers need teaching strategy.

In other term, strategy art to do stratagem (planning). Muhibin Syah says teaching strategy is a set of steps which made to reach the learning purpose. According J. R. David in teaching strategies for college class Room (1976) teaching strategy is a plan, method, or series of activities designed to a particular educational goal. ${ }^{10}$

In this case, Muhibin Syah focuses on a set of step to reach the education purpose, whereas Syaiful, Bahri Djamarah, Aswin Zaini gave a meaning of strategy to a bow line to act in reach target. It is connected to learning teaching process. And strategy can be meant as general pattern of teacher students' activity to scratching purpose. ${ }^{11}$

Differ with them, Douglas give the meaning of strategy deeper to teaching process directly, he said that strategy is specific method of approaching a problem or task, modes of operation for achieving a particular end, planned design for

\footnotetext{
${ }^{7}$ Nickols, Fred, (2010), Journal: Strategy: Definition and Meaning, Distance Consulting, 2010 , p. 2

${ }^{8}$ Abin Syamsuddin Makmun, (2004), Psikologi Kependidikan, Remaja Rosdakarya, Bandung, p. 164

${ }^{9}$ Kinsella, (1985), Cambridge Language Teaching, Cambridge University Press, Cambridge, p. 215

${ }_{10} \mathrm{~J}$. R. David in Muhibbin Syah (2004), Psikologi Pendidikan Dengan Pendekatan Baru, Remaja Rosdakarya, Bandung, p. 214 Jakarta, , p. 5

${ }^{11}$ Syaiful, Bahri Djamarah, (1999), Aswin Zaini, Strategi Belajar Mengajar, Rineka Cipta,
} 
controlling and manipulating certain information. ${ }^{12}$

From the meaning of strategy above, there are some points that it can get. The first, a teacher should have a set of step of teaching to make learning teaching process done well. Second, a teacher should choose the right method in delivering the material to student. The third, both teacher and students must active in teaching learning process, so, the strategy can help them to reach of educational aim. Finally, both teacher and students can feel fund in teaching learning process and the students do not be feel bore in learning the subject that taught by teacher.

\section{Sensory Image Strategy}

It is not easy to apply sensory image strategy. For example, to describe a smell without referring to taste. In fact, we often describe our sensory experiences in relation to other senses. Writers use literary devices, such as similes and metaphors, to help shape our sensory experience of text, to help us make connections between our senses and language; understanding and creating metaphors is one of the research based instructional strategies highlighted in this book. Many picture book authors offer readers powerful similes that connect sensory experiences to a particular time period, landscape, culture, or emotion that may be unfamiliar to a young reader.

Students who can make connections between their sensory experiences and language can then use their senses to comprehend text. In Picture This: Teaching Reading through Visualization, Rose (1989) offers a series of learning experiences to help students develop the ability to visualize. Her lessons involve guided visualizations, some of which are based on excerpts from children's literature. Rose provides listeners with a focus for their imaginations and a specific task to perform at the end of the visualization. In addition to developing the ability to make mental pictures while listening and reading, these lessons also encourage students to incorporate more vivid sensory details in their own writing. ${ }^{13}$

As educators collaborate to plan, implement, and assess sensory-focused lessons, it is essential that they take into account students' individual differences. Some children may not have typical eyesight or hearing. As a result, they may have developed keen sensory ability in another category. Some children may not have the mobility to engage in a variety of kinesthetic experiences; instead of touch, another sense may more fully capture sensory input for them. The classroom teacher's assessment of individual student needs is a critical component of the knowledge she brings to the collaboration. Lessons must be modified or adapted and must be presented in such a way that all learners are given opportunities for sensory

\footnotetext{
${ }^{12}$ Brown, H. Doglas, (2000), Principles of Language Learning and Teaching, Longman, New York, USA., p. 113

${ }^{13}$ lbid. p. 40
} 
development in order to achieve comprehension. Next, the Procedure of Sensory Images Strategy applied.

\section{Before Reading: Connecting to Prior Sensory Knowledge}

Play ocean music softly. Read the title of the book. Ask the students to close their eyes and take a minute to imagine the sights, sounds, tastes, textures, and smells of the ocean. When they open their eyes, brainstorm as many ocean sensory images as possible. The educators can begin the brainstorm and can continue to contribute as the brainstorm builds. Input should be recorded with different colors, one for each sense: sight, hearing, taste, touch, and smell.

\section{During Reading: Activating Sensory Images}

One educator reads; one closes her eyes. The students also close their eyes during the readings of the three passages. Listeners imagine the ocean during the readings.

"The ocean is an old, old man born at the beginning of time. He breathes a loud, salty breath, and his beard blows white on the sandy beach. Fish swim in his long"

The listening educator shares her images and connections with the students. Example:

The idea of the ocean changing conditions like people change their moods made sense to me. This helps me understand that the ocean is always changing. The words gurgles and prattles are onomatopoeia, words that make sounds. These words helped me hear the water in the rock pools. "But at night he's more beautiful than ever. At night he wears a dark, silvery gray cloak with moons and stars sprinkled upon it. Every night before he goes to sleep, he pulls a soft, misty blanket over himself."

The listening educator shares her images and connections with the students. Example:

The final image was very beautiful. I am familiar with the moon and stars in the sky, and I could easily imagine the old wavy hair. On his head he wears a crown of pearls. On his feet he wears shoes of shells."

The listening educator shares her images and connections with the students. Example:

I now live in the desert and grew up in the Midwest, far from the ocean. When the author wrote about how the ocean is an old man, a metaphor, she made it easier for me to imagine the ocean in my mind's eye. Although I have visited the ocean, I have more background knowledge of the images she shares of the old man and of the senses suggested by the words in this passage than I do of the ocean itself. 
I could imagine an old man's long white beard and how the waves that touch the shore are white. I have smelled salty breath. I'm thinking of my husband's breath after he's eaten popcorn or pickles. I could see the fish in my mind's eye, swimming up and down along the waves, waves like the old man's hair. It was fun to imagine the ocean as an old man with a crown of pearls on his head and shoes made from shells on his feet.

"Sometimes the wind blows his hair about in big wild waves. Then he gets angry, and he roars and hisses and spits. When the sun shines, he laughs and gurgles and prattles in the rock pools. He smiles a wide silver and green smile on the beach. On his shoulders he carries ships and boats."

Man wearing them like a wizard's moon-and-stars cloak. The blanket of mist image wasn't as strong for me. I haven't seen mist very often in my life.

\section{After Reading: Reflection}

The listening educator shares her images and connections with the students. Example:

I think the author, who uses the voice of the young girl in the story to describe the ocean in this way, gave me connections to sensory images that helped me experience the ocean more powerfully. I could picture the ocean in my mind because I could relate it to things with which I am familiar, such as an old man, salty breath, and a wizard's cloak. Picturing the ocean in my mind made this passage even more memorable to me. My visualization included sounds and smells as well as visual images. The author's figurative language made the ocean come alive for me. In these passages, the author's words created a truly beautiful movie in my mind. ${ }^{14}$

\section{Strength and Weakness of Sensory Image Strategy}

Every strategy has strength and weakness. Of course sensory image strategy has strength and weakness. After read and understanding of definition and the procedure of the strategy, the writer finds the strength and the weakness of it. The strength are as follows:

- Students become more sophisticated in utilizing their senses.

- Sensory imagery can be combined to show how the senses work together to enhance our understanding and enjoyment of text.

- The students can develop sensory ability in another category.

The weakness are as follows:

- The time is not efficiency.

- The students will not serious in studying if the teacher does not give extra attention to them. 
- The study will not effective if both the teacher and the students do not keep attention each other.

\section{Questioning Strategy}

Questioning is among the social competencies that children bring with them to their schooling. But when they enter school, many children begin to think of questions in terms of answering the teacher's questions rather than asking and answering their own. "It is somewhat ironic that while parents will often complain about the number of questions that children expect them to answer, the opposite is true in schools. In schools, it is the teachers who ask the questions and children who are expected to provide the answers". ${ }^{15}$ Questioning is also a process of talking to oneself about whether the meaning makes sense. ${ }^{16}$

Educators are often skilled at using questions as cues to preview read-aloud selections. After reading the title and the author's and illustrator's names, adult readers usually ask questions to invite students to consider the meaning of the title, to make predictions based on the cover illustration, or to connect the story listeners' background knowledge. Connections to previously shared texts on this topic or theme or to other texts written or illustrated by this author or illustrator help prepare the listeners for what is to come.

Cristie, 2003, in Judi Moreillon said that Introductory questioning is important but, as comprehension builds, asking questions during the reading is likely more important and more challenging to teach and to learn. ${ }^{17}$

From the above explanation the writer can take summary that Questioning is a lifelong skill, can and should be taught across the curriculum. Questioning is an essential component of reading comprehension, of conducting research, and of critical thinking. In short, questioning is a key to learning. In the rapid pace of change of our information-rich 21st century, questioning may be more important than ever by providing readers with a path to follow. Instead of being overwhelmed by information, students can focus on asking and answering questions that are germane to their purposes. In the context of classroom-library collaboration, asking and answering questions while reading texts related to curriculum as well as texts of personal interest are essential to developing information literacy.

Through collaboration, teacher-librarians and classroom teachers can effectively design, implement, and assess lessons that demonstrate the use of questioning to

\footnotetext{
${ }^{15}$ Whitebread, David, ed. (2000), The Psychology of Teaching and Learning in the Primary School, Routledge, New York: p. 70

${ }^{16}$ Gerald G. Duffy, 2009, Explaining Reading a Resource for Teaching Concept, Skills, and Strategies, Second Edition, The Guilford Press, New York, p. 107

${ }^{17}$ Judi Moreillon, Op. Cit., p. 60
} 
engage readers with texts in order to make meaning. Educators can support one another by identifying texts that lead students to ask questions - whether questions inspired by the students' lack of background knowledge or by their motivation to explore the topic or theme of the text.

\section{THE PROCEDURE OF STRATEGY}

\section{Before Reading: Questions Related to the Cover, the Frontispiece, and the Title Page}

One teacher reads the title of the book and the author's and illustrator's names. The other teacher asks himself questions aloud. After the questioner has shared his thinking about the cover (A), the reader turns to the frontispiece (B), and then to the title page $(\mathrm{C})$.

A: I'm thinking about the title of the book. Is the main character named Solomon Singer? Is the man on the cover in the foreground the main character? I wonder who his "angel" is. Why does he need an angel?

When I look at the cover, I wonder about the tall, yellow-brown grass that the illustrator painted in front of the largest character. Why is this man standing in the grass? It seems odd to me that grass is growing right up to the window of the Westway Café. Where is the café? The man in the café probably works there. Is he a cook or a waiter? What is the relationship between the two men on the cover?

B: I can see part of the word "hotel." I think the main character from the cover lives in a hotel. I wonder why his face is downcast. The illustrations are watery and sad in tone. Is this man sad to live in a hotel? Why does he live there instead of in a house or in an apartment? What is the red writing under the window?

C: The man is going up the stairs, probably to his room in the hotel. His face is in shadow. I wonder if he lives alone. I wonder if the illustrator wants us to feel sad when we look at this page in the book. This man does not seem happy.

\section{During Reading: Example from the First Few Pages}

The reader begins and stops at the end of each double-page spread so the listener can answer and ask questions. Before resuming reading, the reader asks the listener why or how posing questions supports his understanding of the text.

I was correct. His name is Solomon Singer, and he does live in a hotel. The hotel is in New York City. The author wrote, "The hotel had none of the things he loved." I wonder what Solomon Singer loves. I notice he's eating his canned soup from a skillet and that his cup has a broken handle. Is he going to eat alone? I wonder if Solomon Singer is poor.

Now I know what he would love to have: a balcony, a fireplace, a porch swing, a picture window, a cat or a dog, and a wall painted yellow or purple. The illustrator paints in the man's favorite things. Does this page show Solomon Singer's 
imagination? Does it show him dreaming about his favorite things? I wonder if it's difficult to have these things because he lives in a hotel in New York City.

I answered my question from the title page. Solomon Singer is unhappy about where he lives. He wanders on the streets. I wonder what it's like to wander at night on the streets in New York City. I see the red writing from the frontispiece is on the hotel door and that there's more writing on the walls outside the hotel. Is this graffiti?

The listener continues to provide this think-aloud dialogue with the text as the reader continues reading and questioning the listener about the benefits of this process.

\section{After Reading: Reflection and Further Questions}

I think the author wants to tell us that friends are like angels. I think that's true. Friends keep us from feeling too sad. They help us feel at home wherever we are.

Asking and sometimes answering my questions as I read helped me become part of the story. I was there with Solomon and Angel at the Westway Café. Now that Solomon has a smile on his face and a friend named Angel, I wonder if Solomon will make other friends.

I think the author and illustrator worked together to create a beautiful story about the importance of friendship. Have Cynthia Rylant and Peter Catalanotto worked together on other books? ${ }^{18}$

\section{STRENGTH AND WEAKNESS OF SENSORY IMAGE STRATEGY}

Every strategy has strength and weakness. Of course questioning strategy has strength and weakness. After read and understanding of definition and the procedure of the strategy, the writer finds the strength and the weakness of it. The strength are as follows:

- use of this strategy encourages increased student motivation and engagement.

- more frequent student-to-student interactions.

- increased student understanding of text, and development of critical thinking skills.

And the weakness are follows:

If the teacher does not care and keep attention to the student, it shall take a lot of time to finish one subject.

\section{READING AND READING COMPREHENSION}

Reading is an extraordinary achievement when one considers the number of levels and components that must be mastered. Consider what it takes to read a simple story. The words contain graphemes, phonemes, and morphemes. ${ }^{19}$ Then, Myra Shulman says that: "Being a good reader means reading actively, efficiently, fairly quickly, and with maximum comprehension. It also means reading for author's

${ }^{18}$ Judi Moreillon, Op. Cit. p. 63

${ }^{19}$ Danielle S. McNamara, (2007), Reading Comprehension Strategies: Theories, Interventions, and Technologies, Lawrence Erlbaum Associates, Inc., New Jersey, p. 3 
general ideas, nor for specific words". ${ }^{20}$ Donn Bryne also says: "Reading ability depends on the ability to perceive and recognize at least or four words at a glance and this ability needs to be trained and encouraged from the early stages of reading onwards." ${ }^{21}$ And David Nunan clarifies that there are seven main purposes for reading:

- To obtain information for some purposes or because we curious about some topics.

- to obtain instructions on how to perform some task for out work or daily life( e.g. knowing an appliance work).

- To act in a play, play game, do a puzzle.

- To keep in touch with friends by correspondence or to understand business letter.

- To know when and where something will take place or what is available.

- To know what is happening or (as happed last reported in newspaper, magazines report).

- For enjoyment or excitement. $^{22}$

From the above quotation, it can be clearly be understood that reading has some viewed points in common reason for reading, namely, reading for measure or enjoyment and reading for getting information or message. In other words intensive or extensive reading.

Comprehension is the active process of constructing meaning from text; it involves accessing previous knowledge, understanding vocabulary and concepts, making inferences, and linking key ideas. Comprehension cannot be learned through rote instruction, but requires a series of strategies that influence understanding of text. Reading comprehension includes the following:

- Applying one's knowledge and experiences to the text,

- Setting goals for reading, and ensuring that they are aligned with the text,

- Using strategies and skills to construct meaning during and after reading,

- Adapting strategies that match the reader's text and goals,

- Recognizing the author's purpose,

- Distinguishing between facts and opinions, and

- Drawing logical conclusions. ${ }^{23}$

Comprehension is usually the ultimate goal of reading. You want to understand

\footnotetext{
${ }^{20}$ Myra Shulman, (1993), Selected Reading in Bussiness, University of Michigan Press, Alaska, p. iii

${ }_{21}^{21}$ Donn Bryne, (1984), Teaching Reading Skill, Singapore, Pour Strong Printing Company, Longman, New York, p. 102

${ }^{22}$ David Nunan, (1999), Second Language Teaching \& Learning, Heinle \& Heinle Publisher, Boston USA., p. 251

${ }^{23}$ Sharon Vaughn, (2004), Sylvia Linan-Thompson, Research-Based Methods of Reading Instruction Grades-K3, ASCD, Alexandria, Virginia USA., p. 98-99
} 
and learn what the author is communicating. More than previous parts though, how well you comprehend material depends on many varied factors. If you want to learn and remember the material, you also have more work to do to retain it for the long term. ${ }^{24}$

The quotation means that reading comprehension is the process of reading to get the purposes of the contents of the text, not to find the meaning. Reading comprehension involves taking meaning to a text in order to obtain the message from that text. And individual may be said to comprehend a text fully when he can:

- Recognize the words and sentences of the text an know what these words and sentences mean (obtain literal meaning)

- Associate meanings, both denotative and connotative, from person experiences with the printed text (obtain inferential meaning)

- Recognize how all these meanings and/or his perception of them fit together contextually.

- Make value judgments about, and based on, the reading experience (read critically).

Then, Paul Douglas Carmine and his friends say that : "Reading skill usually involves decoding and comprehension". ${ }^{25}$ Decoding is translating printed words into a representation similar to oral language (e.g. Reading, either silently or a loud, "I am hot' for the world I am hot) it stresses pronunciation and intonation and the teacher clarifies each concept, while comprehension understand the representation (e.g. Knowing who/in the sentence refers to and how "being hot" feels). The students are trained to comprehend or to understand the meaning or concept without teacher's help.

In reading comprehension, we can see how important it is that the reader and the writer should have a certain thing in common if communication between them is to take place. The minimum equipment is they should share the same code. The writer and the reader should have certain assumption about the understanding of the text. For example, if the writer expects his reader to have a basic understanding of chemistry, the text will not be readily understood by anyone who lacks this.

In this study, the writer will make a rough division the types of reading comprehension. These types based on the Burn C. Burn says: "Reading comprehension consist of four division, those are; literal comprehension, interpretative comprehension, critical reading and creative reading" ${ }^{26}$

\footnotetext{
${ }^{24}$ Sean Whiteley, (2004), Memletics Effective Speed Reading Course, Dramatically Improve Reading Skills to Help You Succeed in today's Fast-Paced World, Published by Advanogy.com, p. 65

${ }^{25}$ Paul Douglas Cornie, et. al., (1982), Direct Instruction Reading, Marrill Publishing Company, 1982), Toronto, p. 37

${ }^{26}$ Burn C. Burn, et.al., (1984), Teaching Reading in Today's Elementary School, Hougton Mifflin Company, Boston, p. 177
} 
From the above quotation can be shown that reading comprehension consist of four divisions, they are literal comprehension, interpretative comprehension, critical reading, and creative reading. Each division needs special skill to do that. So, both teacher and students have to be patient in doing it. As a teacher has to deliver each material by using suitable strategy, so that the students do not be bored in learning it. As students have to be carefully in accepting the material and keep attention in teaching learning process, so they can understand the material clearly.

\section{RESEARCH METHOD}

In this study, there are two variables, they are independent variable and dependent variable.

The independent variable is the implementation of Sensory Images and questioning strategies in teaching reading comprehension, the sensory images and questioning strategy is the strategy that used in teaching reading comprehension as variable $\mathrm{X}$.

In this case I focused on sensory images and questioning strategies and the students' ability in reading comprehension is as variable $\mathrm{Y}$ in this study, the indicators of students' ability in reading comprehension are:

- The students are able to identify main idea and sentence modifier of the main idea.

- The students are able to retell the text by using their own word.

\section{FINDING AND DISCUSSION}

\section{Finding}

The students' ability in reading comprehension that taught by using Sensory Images strategy that shows the lowest score is 45 and highest score is 90.

Mean Score of the test of the students' ability in reading comprehension that taught by using Sensory Images Strategy counted as follows:

$$
\begin{aligned}
\bar{X} & =\frac{\sum f_{i} x_{i}}{\sum f_{i}} \\
& =\frac{1686}{25} \\
& =67.44
\end{aligned}
$$

Variants score is counted as follows:

$$
\begin{aligned}
S^{2} & =\frac{n \sum f_{i} x_{i}^{2}-\left(\sum f_{i} x i\right)^{2}}{n(n-1)} \\
& =\frac{25 x 120208-(1686)^{2}}{25(25-1)} \\
& =\frac{3005200-2842596}{25(24)}
\end{aligned}
$$




$$
\begin{aligned}
& =\frac{162604}{600} \\
S^{2} & =271
\end{aligned}
$$

Deviation standard is found by drawing root of variants that is $\sqrt{271}=16,46$.

The students' ability in reading comprehension that taught by using Questioning Strategy show us the lowest score is 50 and the highest score is 80 .

Mean score of the students' ability in reading comprehension that taught by using Questioning Strategy can be counted as follows:

$$
\begin{aligned}
\bar{X} & =\frac{\sum f_{i} x_{i}}{\sum f_{i}} \\
& =\frac{1621}{25} \\
& =64,84
\end{aligned}
$$

Variants is counted as follows:

$$
\begin{aligned}
S^{2} & =\frac{n \sum f_{i} x_{i}^{2}-\left(\sum f_{i} x i\right)^{2}}{n(n-1)} \\
& =\frac{25 \times 107253-(1621)^{2}}{25(25-1)} \\
& =\frac{2681325-2627641}{25(24)} \\
& =\frac{53684}{600} \\
S^{2} & =89,47
\end{aligned}
$$

Deviation standard is found by drawing root of variants that is $\sqrt{89,47}=9,46$

Based on the analysis data that found in the field that two groups of the data are the data of students' ability in reading comprehension that taught by using Sensory Images Strategy and the data of students' ability in reading comprehension that taught by using Questioning Strategy have fulfilled the condition of statistic hypothesis test of "t". Because of it has done by using normality test and homogeneity test, to make the hypothesis test in this research was used test the equality two mean by using "t" statistic, as follows:

$\mathrm{t}=\frac{\bar{X}_{1}-\bar{X}_{2}}{s \sqrt{\frac{1}{\mathrm{n}_{1}}+\frac{1}{\mathrm{n}_{2}}}}$

Explanation:

$\bar{X}_{1}=$ The group average value sample that has highest score

$\bar{X}_{2}=$ The group average value sample that has lowest score

$S \quad=$ Standard deviation merger is found by using the formula as follows: 


$$
S^{2}=\frac{\left(n_{1}-1\right) s_{1}{ }^{2}+\left(n_{2}-1\right) s_{2}{ }^{2}}{n_{1}+n_{2}-2}
$$

From counting before has found that:

- For the data of sample group of students' ability in reading Comprehension that taught by using Sensory Images Strategy has got the mean score is $=67,44$.

- For the data of sample group of students' ability in reading comprehension that taught by using Questioning Strategy has got the mean score is $=64,84$

- Deviation standard is counted as follows:

$s=\frac{(25-1) 271+(25-1) 89,47}{25+25-2}$

$=\frac{6504+2147,28}{48}$

$=\frac{8651,28}{48}$

$=180,235$

From the variant value merger is 180,235 , the deviation standard merger was from square of variants merger was 13,43.

To test of hypothesis in this research was used test the equality two mean by using "t" statistic as follows:

$$
\begin{aligned}
t & =\frac{67,44-64,84}{13,43 \sqrt{\frac{1}{25}+\frac{1}{25}}} \\
& =\frac{2,60}{1,07} \\
& =2,43
\end{aligned}
$$

The value of $t$-count 2,43 comparing with the value of $t$-table where the value of $\mathrm{t}$-table for real level $\alpha=0,05$ with $\mathrm{dk}=25+25-2$ found the value of $\mathrm{t}_{0,05}(48)=$ 2,021 in the reality the value of $t_{\text {count }}(2,43)>t_{\text {table }}(2,021)$. It means that $t_{\text {count }}$ be at the hypothesis deduction of zero (Ho) rejected and the alternative hypothesis (Ha) accepted. It means that alternative hypothesis that is opened by the writer is " there is significant effect of Sensory Images and Questioning strategy on the students' ability in reading comprehension can be accepted.

\section{DISCUSSION}

The main problem in this research was the effect of sensory images and questioning teaching strategies on the students' ability in reading comprehension. The research show that the result of the test that was given to the students after teaching learning process by using Sensory Images Strategy got higher result than the result test that the students was taught by using Questioning Strategy.

The finding indicates that the use of Sensory Images Strategy is proven effective to 
increase students' ability in reading comprehension. Studying with Sensory Images, students can find many synonyms from one word and the understanding of students is better.

To get the benefit from Sensory Images Strategy especially about students' ability in reading comprehension, the teacher has to select the theme or the topic first. By doing it, the increasing the students' ability in reading comprehension can be reached and can be proven.

At least by using Sensory Images Strategy, the students' ability in reading comprehension is hoped expected to reach the wanted target. The fenomenon that show applying Sensory Images Strategy in studying reading comprehension activity represent an important supplementary factor in study.

In general the source of error in research at liest two matters. Sampling or analysis subject and research instrument. This matter become starting point to identify the research limitation elaborated as follows:

First, quantitave research approach has a problem in measuring things having the character of qualitative. For example from all aspect of students' ability in reading comprehension did not come from qualitative approach. Especially, in applying Sensory Images Strategy to increase students' ability in reading comprehension, and it was influenced by a lot of matter which is not studied in this research, like a level of students' intelligence, enthusiasm and motivate to learn.

The second, there is a probably element deflect from obtained data research, eventhough the instrument that was programmed as good as possible, but in doing test, the students did not seriously.

\section{CONCLUSION}

The end of this writing, the writer can give some conclusions as follows;

- Students' ability in reading comprehension by using Sensory Images Strategy shows the mean score equals to 67.44 .

- Students' ability in reading comprehension by using Questioning Strategy shows the mean score equals to 64.84 .

- Based on the counting of " $t$ " test statistics is scored a point by equals to 2.43 while the price of $t$-table equals to 2.021. This shows that the hypothesis Students' ability in reading comprehension text is effected by Sensory Images Strategy and Questioning Strategy can be accepted. 
IJIERM: Vol. 1 No. 1 September- Desember 2019

\section{REFERENCES}

Abin Syamsuddin Makmun, (2004), Psikologi Kependidikan, Remaja Rosdakarya, Bandung.

Brown, H. Doglas, (2000), Principles of Language Learning and Teaching, Longman, New York, USA.

Bülent Dös*, Erdal Bay, Ceyda Aslansoy, Betül Tiryaki, Nurgül Çetin and Cevahir Duman, (2016), Academic Journal, Educational Research and Reviews, An Analysis of Teachers' Questioning Strategies, Gaziantep University, Nizip Faculty of Education, Turkey.

Burn C. Burn, et.al., (1984), Teaching Reading in Today's Elementary School, Hougton Mifflin Company, Boston.

Byrd, Particia, (1995), Material Writers' Guide, USA: Heinle \& Heinle Publishers.

Danielle S. McNamara, (2007), Reading Comprehension Strategies: Theories, Interventions, and Technologies, Lawrence Erlbaum Associates, Inc., New Jersey.

Danny Brassell, Timothy Rasinski, and Foreword by Hallie Yopp (2008), Comprehension That Works; Taking Students Beyond Ordinary Understanding to Deep Comprehension, Shell Education, Huntington Beach.

David Nunan, (1999), Second Language Teaching \& Learning, Heinle \& Heinle Publisher, Boston USA.

Donn Bryne, (1984), Teaching Reading Skill, Singapore, Pour Strong Printing Company, Longman, New York.

Gerald G. Duffy, 2009, Explaining Reading a Resource for Teaching Concept, Skills, and Strategies, Second Edition, The Guilford Press, New York.

Judi Moreillon, (2007), Collaborative Strategies for Teaching Reading Comprehension Maximizing Your Impact, American Library Association, Chicago, USA.

Kinsella, (1985), Cambridge Language Teaching, Cambridge University Press, Cambridge.

${ }^{1}$ Mary. T, Brownell, (2000), "Dr. Michael Pressley" in Intervention in School and Clinic. Nov. 2000. pages 105-107

Muhibbin Syah (2004), Psikologi Pendidikan Dengan Pendekatan Baru, Remaja Rosdakarya, Bandung.

Myra Shulman, (1993), Selected Reading in Bussiness, University of Michigan Press, Alaska.

Nickols, Fred, (2010), Journal: Strategy: Definition and Meaning, Distance Consulting.

Paul Douglas Cornie, et. al., (1982), Direct Instruction Reading, Marrill Publishing Company, Toronto.

Raphael, Taffy E., (1982). "Question-Answering Strategies for Children." The Reading 
Teacher 36, November, 1982.

Sean Whiteley, (2004), Memletics Effective Speed Reading Course, Dramatically Improve Reading Skills to Help You Succeed in today's Fast-Paced World, Published by Advanogy.com.

Sharon Vaughn, (2004), Sylvia Linan-Thompson, Research-Based Methods of Reading Instruction Grades-K3, ASCD, Alexandria, Virginia USA.

Syaiful, Bahri Djamarah, (1999), Aswin Zaini, Strategi Belajar Mengajar, Rineka Cipta, Jakarta.

Whitebread, David, ed. (2000), The Psychology of Teaching and Learning in the Primary School, Routledge, New York. 